Original article

\title{
Chemical compounds of oak (Quercus petraea (Matt.) Liebl.) species with different medicinal properties in eastern Black Sea region
}

\author{
Ibrahim Tumen***, Sanver Eyuboglu*, Mehmet Kurtca** and Nazim Sekeroglu*** \\ *Department of Forest Products Chemistry, Faculty of Forestry, Bartin University, Bartin-74100, Turkey \\ **Vocational School of Health Services, Bartin University, Bartin-74100, Turkey \\ ***Medicinal and Aromatic Plant Programme, Plant and Animal Sciences Department, Vocational School, \\ Kilis Aralik University, Kilis-79000, Turkey
}

Received January 2, 2018: Revised February 15, 2018: Accepted February 20, 2018: Published online June 30,2018

\section{Abstract}

Oak (Quercus petraea (Matt.) Liebl.) has many medicinal values. It was observed that many researchers have reported about anti-inflammatory, wound healing, anthelmintic, antibacterial and antioxidant effects of this plant. In our study, the quantities of chemical composition of heartwood, sapwood and bark of Strendzha oak (Quercus hartwissiana), Sessile oak (Quercus petraea) and eastern Black Sea oak (Quercus pontica) have been determined by means of standard methods. Additionally, chemical components of the heartwood, sapwood and bark of Strendzha oak (Q. hartwissiana) were analyzed by GC-MS. As a result of GC-MS analyses, the compounds identified in heartwood with higher ratio were octacosane $(5.50 \%)$, heptacosane $(4.44 \%)$ and hexacosane $(2.76 \%)$ while those in sapwood were found octacosane $(7.09 \%)$, triacontane $(6.50 \%)$ and heptacosane $(4.72 \%)$. In addition to this, vitamin $\mathrm{E}(5.38 \%)$, stigsmastan-3,5-dien $(2.53 \%)$ and campestrol $(1.85 \%)$ were found in higher ratio in the bark of Strendzha oak.

Key words: Oak (Quercus petraea (Matt.) Liebl.), GC-MC, chemical compounds, different medicinal properties

\section{Introduction}

Oak (Quercus petraea (Matt.) Liebl.) grows in large forests in temperate, tropical regions and high mountainous parts of northern hemisphere with more than two hundred species, many subspecies, varieties and natural hybrid. There are 450 varieties of $Q$. petraea on this planet. Turkey has 18 varieties of $Q$. petraea species that grow naturally, four of them are endemic. Oak species (Strendzha oak-Q. hartwissiana; Sessile oak-Q. petraea and east Black Sea oak-Q. pontica ) grow extensively in eastern Black Sea region of Turkey (Hedge and Yaltirik, 1982; Yaltirik, 1984; Todaro et al., 20131; Demeter et al., 2014; Keten et al., 2015; Sen et al., 2016; Yilmaz, 2017).

Sessile oak $(Q$. petraea $)$ is a forest tree which can grow longer up to $30 \mathrm{~m}$. They have long leaf and their length is $12 \mathrm{~cm}$. Moreover, its acorns sit on the twigs without stem. On the other hand, Strendzha oak can grow longer up to $25 \mathrm{~m}$. Its leaf length is in the range of 8$15 \mathrm{~cm}$. In addition to this, its berry stem has 2-7 cm length and there are 3-4 berries in a stem. Eastern Black Sea oak has also 3-5 $\mathrm{m}$. length. Its leaves length is $20-30 \mathrm{~cm}$ and they have short stem

\footnotetext{
Author for correspondence: Dr. Ibrahim Tumen

Department of Forest Products Chemistry, Faculty of Forestry, Bartin University, Bartin-74100, Turkey

E-mail: tumen@bartin.edu.tr

Tel.: +90-3782235074
}

Copyright @ 2018 Ukaaz Publications. All rights reserved.

Email: ukaaz@yahoo.com; Website: www.ukaazpublications.com
(Yaltirik, 1984; Ansin and Özkan, 1999; Ansin and Terzioglu, 2001).

In our country, hardwood of oak tree is usually used in timber, construction and furniture industry. Additionaly, fuelwood and cork are used for insulation and erosion control. Also, acorns and leaves of Quercus is an important food source for animals and wildlife (Cypert and Burton, 1948; Bainbridge 1986; Lieutaghi, 1998.). However, it is known that oak ( $Q$. petraea) is also used medically in public. Some species $(Q$. robur, $Q$. cerries and $Q$. ithaburensis subs.) of oak are used against throat diseases, stomach and constipation discomforts (Baytop, 2001). Furthermore, it is indicated that oak barks and acorns have astringent and antiseptic effects. Moreover, it is included in ointments used as wound healing agents (Bremness, 1994).

In addition to what we have already mentioned above, the Quercus tree (oak) has a long history of medicinal uses. It is antiinflammatory, antiseptic, astringent, decongestant, haemostatic, bronchitis, diabetes, tonsillitis, as well as gonorrhea and tonic. The bark is the part of the plant that is most commonly used, though other parts such as the galls, seeds and seed cups are also sometimes used. In general, a decoction of the bark is useful in the treatment of chronic diarrhoea, dysentry, intermittent fevers, haemorrhages, etc. Externally, it is used to bathe wounds, skin eruptions, sweat feet, piles, etc. It is also used as a vaginal douche for genital inflammations and discharge and also as a wash for throat and mouth infections; besides in the treatment of disorders of spleen and gall bladder 
(Popovie et al., 2013; Petrovska, 2012; Shah et al., 2014; Orszaghova et al., 2015, Lorzadeh et al., 2016).

\section{Materials and Methods}

\subsection{Plant material}

Species, region, diameter and altitude information of samples are shown in Table 1. Because fiber length and chemical compounds in different parts of oak trees can be different, samples were collected from bottom, middle and top of oak trees.

\subsection{Sample preparation for chemical analysis}

Woods and barks were collected from sample trees and wood chips were prepared by hand as size of matchstick and then dried in clean and airy place. They were ground by Wiley grinder according to Tappi $257 \mathrm{om}-2002$. The samples were stored in glass jars (Tappi, 2002).

Table 1: Information of samples

\begin{tabular}{|l|l|c|c|c|}
\hline Tree species & Region & $\begin{array}{c}\text { Diameter } \\
(\mathbf{c m})\end{array}$ & $\begin{array}{c}\text { Altitude } \\
(\mathbf{m})\end{array}$ & Symbol \\
\hline Sessile oak & Gumushane & 27 & 710 & $\mathrm{I} 1$ \\
(Q. petraea & & 28 & 720 & $\mathrm{I} 2$ \\
(Matt.) Liebl.) & & 34 & 725 & $\mathrm{I} 3$ \\
\hline Strendzha oak & Trabzon & 42 & 350 & $\mathrm{H} 1$ \\
$($ Q. hartwissiana) & & 45 & 355 & $\mathrm{H} 2$ \\
& & 47 & 370 & $\mathrm{H} 3$ \\
\hline Eastern Black & Rize & 13 & 1700 & $\mathrm{P} 1$ \\
Sea oak & & 14 & 1735 & $\mathrm{P} 2$ \\
$($ Q. pontica $)$ & & 11 & 1760 & $\mathrm{P} 3$ \\
\hline
\end{tabular}

\subsection{Hot water solubility}

Hot water solubility test was done according to Tappi, 207 om1999 standard. Two gram of dried samples (heartwood, sapwood and bark) were transferred to a $250 \mathrm{ml}$ Erlenmeyer flask and $100 \mathrm{ml}$ of hot distilled water was added. Then, the solution was boiled at $100^{\circ} \mathrm{C}$ for $3 \mathrm{~h}$. under the reflux condenser. The contents of the flask were transferred to a tared filteringcrucible which has been previously dried to a constant weight at $105 \pm 2^{\circ} \mathrm{C}$, washed with $200 \mathrm{ml}$ of hot water and dried to constant weight at $105 \pm 3^{\circ} \mathrm{C}$. After samples were dried, they were placed in a desiccator and weighed. Amount of solute was calculated according to equation 1.

Hot and cold water solubility, $\%=[(\mathrm{A}-\mathrm{B}) / \mathrm{A}] \times 100$

where, A: initial weight of the test specimen, g oven dry.

B: weight of the test specimen after extraction, g equation 1 .

\subsection{Cold water solubility}

This test was also done according to Tappi 207 om-1999 standard. Two gram of dried samples (heartwood, sapwood and bark) were transferred to a $500 \mathrm{ml}$ Erlenmeyer flask and $300 \mathrm{ml}$ of distilled water was added. Then, the solution was kept at $23^{\circ} \mathrm{C}$ for $48 \mathrm{~h}$. After $48 \mathrm{~h}$., the procedure continued as hot water solubility test (Tappi, 1999).

\subsection{Alcohol solubility}

Tappi 204 om-1997 was applied for this test. Two gram of dried samples (heartwood, sapwood and bark) were extracted in $350 \mathrm{ml}$ ethanol by soxhlet apparatus for $6 \mathrm{~h}$. After this time, extracts were dried to constant weight in oven. Then, they placed in a desiccator and amount of solute was calculated according to equation 1 (Tappi, 1997).

\section{$2.6 \% 1 \mathrm{NaOH}$ solubility}

According to Tappi 212 om-2002 standard, two gram of dried samples (heartwood, sapwood and bark) were transferred to a 200 $\mathrm{ml}$ Erlenmeyer flask, $100 \mathrm{ml}$ of $\% 1 \mathrm{NaOH}$ solution was added. Then, Erlenmeyer was waited in $100^{\circ} \mathrm{C}$ water bath for $1 \mathrm{~h}$. After 1 h., residue in Erlenmeyer was filtered by tared filtering crucible and then washed with $50 \mathrm{ml}$ of $\% 10$ acetic acid and hot distilled water. The procedure continued as hot water solubility test.

\subsection{Hexane solubility}

Sixty gram of wood samples (heartwood, sapwood) and 120 g. of bark samples were extracted in $350 \mathrm{ml}$ hexane by Soxhlet apparatus for $11 \mathrm{~h}$. After $11 \mathrm{~h}$, the procedure continued as $\% 1 \mathrm{NaOH}$ solubility test (Tappi, 2002).

\subsection{Holocellulose analysis}

Method which was applied by Wise et al. (1945), was used for this analysis. Five gram of dried samples (heartwood, sapwood and bark) which were extracted in alcohol, $160 \mathrm{ml}$ distillated water, 1,5 $\mathrm{g}$ sodium chloride and $0.5 \mathrm{ml}$ iced acetic acid were transferred to a $250 \mathrm{ml}$ Erlenmeyer and waited in $78-80^{\circ} \mathrm{C}$ hot water bath for $1 \mathrm{~h}$. After $1 \mathrm{~h}$., $0.5 \mathrm{ml}$. iced acetic acid and $1.5 \mathrm{~g}$, sodium chloride were added to the Erlenmeyer and this procedure was repeated three times. Then, the solution was filtered by glass crucible and washed with acetone and cold distilled water. They were dried at $103^{\circ} \mathrm{C}$ and weighed. The amount of holocellulose was calculated according to equation 2 (Wise and Karl, 1962; Browning, 1967).

$$
\% \text { Holocellulose }=(\mathrm{A}) /(\mathrm{B}) \times 100
$$

where, A: initial weight of the test specimen, g oven dry

$$
\text { B: weight of the test specimen after extraction, g Equation } 2
$$

\subsection{Cellulose analysis}

Kurschner and Hoffer's method was used for the cellulose analysis. Two gram of dried samples (heartwood, sapwood and bark) which were extracted in alcohol were transferred to a flask. $10 \mathrm{ml}$ of $\mathrm{HNO}_{3}$ and $40 \mathrm{ml}$ of ethyl alcohol were added to the flask. This solution was boiled in water bath under the reflux condenser for one hour. After $1 \mathrm{~h}$, the residue was filtered. Then, $10 \mathrm{ml}$ of $\mathrm{HNO}_{3}$ and $40 \mathrm{ml}$ of ethyl alcohol were added to residue. This solution was boiled again and this procedure was repeated three times (Eroglu, 1988; Han and Rowell, 1997). After this, the procedure continued as holocellulose analysis.

\subsection{Lignin analysis}

Lignin analysis was done according to Tappi 211 om-2002 standard method. $1 \mathrm{~g}$. of dried samples (heartwood, sapwood and bark) which were extracted in alcohol, were transferred to a beaker. Then, $15 \mathrm{ml}$ of $72 \%$ sulfuric acid was added to this beaker and waited for $2 \mathrm{~h}$. at $12-15^{\circ} \mathrm{C}$. After this, the solution was transferred to one litre Erlenmeyer. The solution had been diluted by distilled water until acid concentration was $3 \%$. Then, this mixture was boiled under the reflux condenser for $4 \mathrm{~h}$. The residue was filtered and washed with hot water. The extract was dried at $103^{\circ} \mathrm{C}$. The amount of lignin was calculated by equation 2 (Tappi, 2002). 


\subsection{Sample preparation for GC-MS analysis}

Fifteen gram of dried samples (heartwood, sapwood and bark) were extracted in $350 \mathrm{ml}$ hexane by Soxhlet apparatus for $11 \mathrm{~h}$. After the extraction, the solvent was evaporated. Extract was dissolved in chloroform, filtered by $45 \mu \mathrm{m}$ filtration and stored in 2 $\mathrm{ml}$ vial in deep freeze for GC-MS analysis (Hafizoglu, 1997; Kilic et al., 2010).

\subsection{GC-MS analysis}

The GC-MS analysis was performed using an HP-Agilent 68905973 GC-MSD instrument equipped HP-5 capillary column (30 m x $0.25 \mathrm{~mm}$ i.d., $0.25 \mu \mathrm{m}$ film thickness). Helium was used as carrier gas at $1.3 \mathrm{ml} / \mathrm{min}$ flow-rate. The column oven was programmed starting from $60^{\circ} \mathrm{C}(2 \mathrm{~min})$ to $260^{\circ} \mathrm{C}$, at $5^{\circ} \mathrm{C} / \mathrm{min}$ heating rate. The split-injector and MS-transfer line were held at 260 and $280^{\circ} \mathrm{C}$, respectively. The MSD was operated in electron impact ionization mode at $70 \mathrm{eV}$ (Hafizoglu and Reunanen, 1997).

\section{Results and Discussion}

\subsection{Solubility tests}

Solubility results of all samples are shown in Table 2. When looking at the Table 2, the highest solubility percentages are in $\% 1 \mathrm{NaOH}$ for all samples. On the other hand, the lowest solubility percentages are also in hexane. Moreover, the highest solubility in $\% 1 \mathrm{NaOH}$, cold water, hot water, alcohol, and hexane percentages were observed in the East Black Sea oak bark as 41,88 \%, $16.98 \%, 23.81 \%, 18.85$ $\%$ and $1.49 \%$, respectively.

Table 2: Solubility results of heartwood, sapwood and bark of samples

\begin{tabular}{|l|c|c|c|c|c|c|}
\hline \multicolumn{2}{|c|}{ Sample } & $\begin{array}{c}\text { Cold water sol. } \\
(\%)\end{array}$ & $\begin{array}{c}\text { Hot water } \\
\text { sol. (\%) }\end{array}$ & $\begin{array}{c}\text { Alcohol sol. } \\
(\%)\end{array}$ & $\begin{array}{c}\text { \%1 NaOH } \\
\text { sol. (\%) }\end{array}$ & $\begin{array}{c}\text { Hexane sol } \\
(\%)\end{array}$ \\
\hline \multirow{4}{*}{ Heartwood } & $\mathrm{I}_{\text {av. }}$ & $5.84 \pm 0.04$ & $9.64 \pm 0.01$ & $6.20 \pm 0.03$ & $23.32 \pm 0.01$ & $0.56 \pm 0.02$ \\
& $\mathrm{H}_{\text {av. }}$ & $10.76 \pm 0.06$ & $15.10 \pm 0.01$ & $10.80 \pm 0.10$ & $30.30 \pm 0.01$ & $0.49 \pm 0.09$ \\
& $\mathrm{P}_{\text {av. }}$ & $8.17 \pm 0.06$ & $14.38 \pm 0.07$ & $7.17 \pm 0.08$ & $31.49 \pm 0.07$ & $0.60 \pm 0.05$ \\
& $\mathrm{I}_{\text {av. }}$ & $3.23 \pm 0.10$ & $5.47 \pm 0.04$ & $3.17 \pm 0.05$ & $19.29 \pm 0.01$ & $0.41 \pm 0.02$ \\
Sapwood & $\mathrm{H}_{\text {av. }}$ & $5.45 \pm 0.07$ & $9.03 \pm 0.04$ & $5.35 \pm 0.13$ & $26.41 \pm 0.13$ & $0.42 \pm 0.01$ \\
& $\mathrm{P}_{\text {av. }}$ & $4.37 \pm 0.02$ & $8.72 \pm 0.08$ & $4.05 \pm 0.06$ & $27.03 \pm 0.01$ & $0.53 \pm 0.02$ \\
& $\mathrm{I}_{\text {av. }}$ & $8.63 \pm 0.01$ & $11.65 \pm 0.05$ & $8.66 \pm 0.06$ & $35.58 \pm 0.01$ & $1.35 \pm 0.01$ \\
Bark & $\mathrm{H}_{\text {av. }}$ & $11.99 \pm 0.02$ & $15.08 \pm 0.05$ & $14.13 \pm 0.12$ & $39.94 \pm 0.01$ & $1.43 \pm 0.01$ \\
& $\mathrm{P}_{\text {av. }}$ & $16.98 \pm 0.06$ & $23.81 \pm 0.01$ & $18.85 \pm 0.12$ & $41.88 \pm 0.01$ & $1.49 \pm 0.03$ \\
\hline
\end{tabular}

av: Average of 3 different tree samples

I: Sessile oak, H:Strendzha oak, P:East Blacksea oak

\subsection{Chemical analysis}

Table 3: Cell wall components of heartwood, sapwood and bark of samples

\begin{tabular}{|l|c|c|c|c|}
\hline \multicolumn{2}{|c|}{ Sample } & Lignin (\%) & Holocellulose (\%) & Cellulose (\%) \\
\hline \multirow{4}{*}{ Heartwood } & $\mathrm{I}_{\text {av. }}$ & $25.07 \pm 0.03$ & $81.4 \pm 0.05$ & $48.08 \pm 0.05$ \\
\cline { 2 - 5 } & $\mathrm{H}_{\text {av. }}$ & $23.04 \pm 0.02$ & $82.88 \pm 0.06$ & $46.43 \pm 0.01$ \\
\cline { 2 - 5 } & $\mathrm{P}_{\text {av. }}$ & $22.19 \pm 0.07$ & $94.90 \pm 0.07$ & $46.10 \pm 0.07$ \\
\hline \multirow{4}{*}{ Sapwood } & $\mathrm{I}_{\text {av. }}$ & $23.10 \pm 0.01$ & $84.04 \pm 0.08$ & $49.38 \pm 0.13$ \\
\cline { 2 - 5 } & $\mathrm{H}_{\text {av. }}$ & $22.26 \pm 0.01$ & $81.47 \pm 0.11$ & $43.46 \pm 0.02$ \\
\cline { 2 - 5 } & $\mathrm{P}_{\text {av. }}$ & $21.64 \pm 0.04$ & $83.28 \pm 0.10$ & $43.45 \pm 0.04$ \\
\hline \multirow{3}{*}{ Bark } & $\mathrm{I}_{\text {av. }}$ & $32.06 \pm 0.02$ & $73.20 \pm 0.08$ & $36.29 \pm 0.04$ \\
\cline { 2 - 5 } & $\mathrm{H}_{\text {av. }}$ & $18.03 \pm 0.02$ & $75.50 \pm 0.08$ & $37.54 \pm 0.08$ \\
\cline { 2 - 5 } & $\mathrm{P}_{\text {av. }}$ & $32.57 \pm 0.02$ & $70.22 \pm 0.17$ & $34.12 \pm 0.04$ \\
\hline
\end{tabular}

av: Average of 3 different tree samples.

I: Sessile oak, H:Strendzha oak, P:East Blacksea oak

Table 3 shows cell wall components of heartwood, sapwood and bark of samples. The investigation of Table 3 implies that the highest holocellulose amount was in East Blacksea oak heartwood as $94.90 \%$. On the other hand, it is shown that East Blacksea oak bark has the highest lignin amount as $32.57 \%$. The highest cellulose amount was also Sessile oak sapwood as $49.38 \%$. 
3.3 GC-MS analysis

Table 4: Per cent composition of chemical compounds of Strendzha oak (Quercus hartwissiana) heartwood, sapwood and bark

\begin{tabular}{|c|c|c|c|c|c|}
\hline Nr. & R.T. & Compounds & Heartwood & Sapwood & Bark \\
\hline 1 & 5.94 & Hexanoic acid & - & - & 0.70 \\
\hline 2 & 11.23 & 4-acetyl-Morpholine & - & - & 0.15 \\
\hline 3 & 11.65 & Decanal & 0.03 & - & 0.05 \\
\hline 4 & 11.77 & Ethyl ester, morpholine-4-carboxylic acid & - & 0.08 & 0.14 \\
\hline 5 & 12.09 & Exo-2-Hydeoxycineole & - & - & 0.09 \\
\hline 6 & 13.22 & Cyclic 1,2:3,4-bis (ethylboronate), a D Ribopyranose, & - & - & 0.08 \\
\hline 7 & 13.98 & 2.4-Decadienal, (E,E) & - & - & 0.40 \\
\hline 8 & 16.68 & 3-hydroxy-4-methoxy benzaldehyde & 0.26 & - & 0.12 \\
\hline 9 & 19.53 & 2,4-di-tert-butyl phenol & 0.21 & 0.15 & 0.10 \\
\hline 10 & 19.80 & 4-ethoxy- ethyl ester Benzoic acid & - & 0.47 & 0.24 \\
\hline 11 & 19.91 & 4-(acetyloxy)-3-methoxy Benzaldehyde & 1.12 & - & - \\
\hline 12 & 20.23 & $\begin{array}{l}\text { 3,4-dihydro-8-hydroxy-3-mehyl-, (R)-, } 2 \text { Benzopyran-1- } \\
\text { one }\end{array}$ & - & - & 0.17 \\
\hline 13 & 21.14 & Propano 3-methoxy-4-hydroxyphenone & 0.11 & - & - \\
\hline 14 & 21.37 & ү-Gurjunene & - & 0.15 & - \\
\hline 15 & 21.51 & $\begin{array}{l}\text { 2-methyl-, 1-(1,1-dimethylethyl)-2-methyl-1,3-propanediyl } \\
\text { ester, Propanoicacid }\end{array}$ & 0.11 & - & - \\
\hline 16 & 22.27 & ү-Eudosmol & - & 0.11 & - \\
\hline 17 & 22.51 & $\begin{array}{l}\text { 2-isopropyl-5-methyl-9methylene- Bicyclo [4.4.0]dec-1- } \\
\text { ene }\end{array}$ & - & 0.32 & - \\
\hline 18 & 22.56 & $\begin{array}{l}\text { 4-(3-hydroxy-1-butenyl)-3,5,5-trimethyl-, 2-Cyclohexen-1- } \\
\text { one }\end{array}$ & 0.20 & - & - \\
\hline 19 & 22.78 & $\alpha .-$ Cadinol & - & 0.66 & - \\
\hline 20 & 22.89 & 4-hydroxy-3,5-dimethoxy-, Benzaldehyde & 0.32 & - & - \\
\hline 21 & 23.63 & Tetradecanyl ester acrylicacid & 0.46 & 0.24 & \\
\hline 22 & 23.95 & Benzoic acid,2,4-dihydroxy-3,6-dimethyl- methylester & - & - & 0.23 \\
\hline 23 & 24.08 & Tetradecanal & - & 0.15 & - \\
\hline 24 & 24.38 & 4,6-Dimethoxysalicylaldehyde & 0.60 & 0.10 & - \\
\hline 25 & 24.44 & 1-Decene & - & - & 0.18 \\
\hline 26 & 25.89 & Octadecane & 0.42 & - & 0.08 \\
\hline 27 & 26.80 & 6,10,14-trimethyl-, 2-Pentadecanone & 0.51 & 0.16 & 0.51 \\
\hline 28 & 27.02 & $\begin{array}{l}\text { 4-Hydroxy-2-methoxycinnamaldehyde,1,2-Benzenedi } \\
\text { carboxylic acid }\end{array}$ & 0.06 & - & - \\
\hline 29 & 27.27 & Bis(2-methylpropyl) esterBenzenedicarbozylic acid & 0.27 & 0.19 & 0.26 \\
\hline 30 & 27.91 & Nonadecane & - & - & 0.07 \\
\hline
\end{tabular}




\begin{tabular}{|c|c|c|c|c|c|}
\hline 31 & 28.27 & Farnesyl acetone $b$ & - & - & 0.12 \\
\hline 32 & 28.42 & Methyl ester hexadecanoic acid & - & - & 0.07 \\
\hline 33 & 28.74 & $\begin{array}{l}\text { 1,4-dimethyl-3-(2-methyl-1-propene-1-yl)-4-vinyl- } \\
\text { Cycloheptene }\end{array}$ & - & 0.16 & - \\
\hline 34 & 29.11 & Butyl 2-ethylhexyl ester, 1,2-Benzenedicarboxylic acid & - & 0.21 & - \\
\hline 35 & 29.83 & Eicosane & 0.08 & 3.28 & 0.08 \\
\hline 36 & 30.22 & Hexadecanal & - & - & 0.11 \\
\hline 37 & 31.17 & Ethyl linoleate & 0.09 & - & \\
\hline 38 & 31.38 & 1-Octadecene & 0.31 & - & 0.86 \\
\hline 39 & 31.56 & 8-Methyl-9-tetradecenoic acid & - & - & 0.15 \\
\hline 40 & 31.57 & 9,12-Octadecadienoic acid Methyl ester, & 0.14 & - & - \\
\hline 41 & 31.68 & Heneicosane & 0.30 & 0.30 & - \\
\hline 42 & 32.47 & 9,12-Octadecadienoic acid & 0.14 & - & 0.17 \\
\hline 43 & 32.82 & 1-Methylbicyclo [3.2.1.] octane & - & - & 0.14 \\
\hline 44 & 33.08 & 9-Octadecenamide & - & - & 0.07 \\
\hline 45 & 33.45 & Docosane & 0.66 & 0.66 & - \\
\hline 46 & 33.46 & Heptadecane & - & - & 0.12 \\
\hline 47 & 33.88 & 1,19-Eicosadiene & - & - & 0.27 \\
\hline 48 & 34.95 & 1-Heptadecene & - & - & 2.57 \\
\hline 49 & 35.15 & Tricosane & 2.18 & 1.53 & - \\
\hline 50 & 35.59 & Methyletherbenzyl & - & - & 0.21 \\
\hline 51 & 35.82 & Z-8-Methyl-9-tetradecenoic acid & - & - & 0.17 \\
\hline 52 & 36.02 & 4,8,12,16-Tetramethylheptadecan-4-olide & - & - & 1.25 \\
\hline 53 & 36.61 & 1-Eicosanol & 0.77 & 0.09 & 0.41 \\
\hline 54 & 36.79 & Tetracosane & 1.98 & 1.94 & 0.46 \\
\hline 55 & 36.97 & Octadecyl ester, Aceticacid & 0.09 & - & - \\
\hline 56 & 37.15 & 9,12-Octadecadienoic acid (Z,Z)-, 2-hydroxy-1-ethyl ester & 0.16 & - & - \\
\hline 57 & 37.89 & LinoleicacidButyl ester & 4.31 & - & - \\
\hline 58 & 37.90 & Isopropyllinoleate & - & - & 6.29 \\
\hline 59 & 38.23 & 1-Octadecanol & - & - & 3.66 \\
\hline 60 & 38.37 & Pentacosane & 2.58 & - & - \\
\hline 61 & 38.50 & Hexadecanoic acid,2,3-dihydroxypropyl ester & - & - & 3.48 \\
\hline 62 & 39.77 & $\gamma$-Sitosterol & - & - & 1.77 \\
\hline 63 & 39.88 & Hexacosane & 2.76 & - & - \\
\hline 64 & 41.35 & Heptacosane & 4.44 & 4.72 & - \\
\hline 65 & 42.58 & 1-ethenyloxy-Hexadecane & 0.46 & 0.50 & - \\
\hline 66 & 42.63 & 2,3-dihydroxypropylester,9,12-Octadecadienoic acid (Z,Z)- & 0.96 & - & - \\
\hline 67 & 42.81 & Octacosane & 5.50 & 7.09 & 1.01 \\
\hline 68 & 43.26 & $\begin{array}{l}\text { 2,6,10,15,19,23-hexamethyl-,2,6,10,14,18,22 } \\
\text { Tetracosahexaene }\end{array}$ & 1.79 & 2.26 & 3.44 \\
\hline 69 & 43.73 & 6-fluoro-4,6-cholestadiene-3-ol & - & - & 1.67 \\
\hline 70 & 43.82 & Nonacosane & 1.93 & 1.62 & 1.12 \\
\hline 71 & 44.28 & 13-Tetradecen-1-ol acetate & 0.76 & 0.94 & 0.99 \\
\hline 72 & 46.35 & Stigmastan-3,5-dien & 0.88 & 4.24 & 2.53 \\
\hline 73 & 46.60 & Triacontane & - & 6.50 & - \\
\hline 74 & 47.73 & Y-Tocopherol & - & - & 1.05 \\
\hline 75 & 49.41 & 5-ethenyl-, $(5, \beta)-$, A-Norcholestan-3-one & - & - & 0.79 \\
\hline 76 & 49.96 & Vitamin E & 4.05 & 3.35 & 5.38 \\
\hline 77 & 51.97 & $\alpha$-Tocopherol, D & 0.23 & 3.18 & - \\
\hline 78 & 52.44 & Campesterol & - & - & 1.85 \\
\hline 79 & 53.52 & Spinasterone & 5.29 & - & - \\
\hline
\end{tabular}


40 compounds in heartwood, 30 compounds in sapwood, 48 compounds in bark were identified by GC-MS (Table 4). The main compounds were observed as tricosane $(2.18 \%)$, tetracosane $(\% 1,98 \%)$, linoleic acid butyl ester $(4.31 \%)$, pentacosane $(2.58 \%)$, hexacosane $(2.76 \%)$, heptacosane $(4.44 \%)$, octacosane $(5,50)$, vitamin $\mathrm{E}(4,05 \%)$, spinasterone $(5,29 \%)$ in heartwood. In sapwood, eicosane $(3.28 \%)$, heptacosane $(4.72 \%)$, octacosane $(7,09 \%)$, 2,6,10,15,19,23-hexamethyl-,2,6,10,14,18,22 tetraco-sahexaene (2.26\%), stigmastan-3,5-dien (4.24\%), triacontane $(6.50 \%)$, vitamin E (3.35\%), $\alpha$-tocopherol, D (3.18\%) were present in their highest amounts. On the other hand, 1-heptadecene $(2.57 \%)$, Isopropyl linoleate $(6.29 \%)$, 1-octadecanol $(3.66 \%)$, hexadecanoic acid,2,3dihydroxypropyl ester $(3,48 \%), 2,6,10,15,19,23$-hexamethyl,2,6,10,14,18,22 tetracosahexaene (3.44\%), stigmastan-3,5-dien $(2.53 \%)$, vitamin E $(5.38 \%)$ were found in bark.

\section{Conclusion}

This study is one of the rare chemical analysis works which was done on heartwood, sapwood and bark of Strendzha oak (Q.hartwissiana), Sessile oak (Q. petraea) and Eastern Black Sea oak (Q.pontica), grown in Eastern Black Sea region. This present study shows that these oak species grown in Eastern Black Sea region have rich extractive content. Particularly, their barks have percentage of 8.66-18.85\% extractive component. Also, in heartwoods and sapwoods, there are percentages of 6.20-10.80\% and $3.17-5.35 \%$ extractive component, respectively. On the other hand, in heartwoods, sapwoods and barks of Strendzha oak, 40,30 and 48 compounds were identified, respectively by GC-MS.

It is important to note that resolution values of barks of oak species grown in Eastern Black Sea region are higher than resolution values of heartwoods and sapwoods. When oak species were compared to angiosperm tree species, chemical compounds and resolution values of woods of Strendzha oak, Sessile oak and Eastern Black Sea oak were found quite high.

\section{Acknowledgements}

A part of the study was presented orally at $3^{\text {rd }}$ Mediterranean Symposium on Medicinal and Aromatic Plants, April, 2017, Girne-T.R.N.C

\section{Conflict of interest}

We declare that we have no conflict of interest.

\section{References}

Ansin, R. and Özkan, Z.C. (1999). Tohumlu Bitkiler 2. Baski, K.T.Ü. GenelYayin No: 167.Trabzon: OrmanFakültesi Yayin, 19:512.

Anpin, R. and Terzioglu, S. (2001). DiriÖrtüDersNotlari. K.T.Ü. GenelYayin No: 210.Trabzon:OrmanFakültesiYayin, K.T.Ü. Basimevi, 32:392.

Bainbridge, D.A. (1986). Use of acorns for food in California: Past, present, future. Presented at the Symposium on Multiple-use Management of California's Hardwoods, pp:12-14.

Baytop, T. (2001). Türkiye' de BitkilerleTedavi (GecmisteveBugün), 2. Baski. Istanbul: Nobel Tip Kitabevleri Ltd. Sti., pp:294-296.

Boris M. Popovic; Dubravka Stajner; Ruzica Zolero; Saso Oriovic and Zoran Galic (2013). Antioxidant characterization of oak extracts combining spectrophotometric assayes and chemometrics. Scientific Wood Journal, Doi: 10.1155/2013/134656.

Biljana Bauer Petrovska (2012). Historical reveiw of medicinal plants usage. Pharmacogn. Rev., 6(11):1-5.

Bremness, L. (1994). Herbs, Dorling Kindersley Limited, London, pp:81.

Browning, B.L. (1967). Methods of Wood Chemistry. New York: Interscience Publisher.

Cypert, E. and Burton, S.W. (1948). Yield and use by wildlife of acorns of water and willow oaks. J. Wildlife Manage., 12(3):227-231.

Demeter, Z.; Kanalas, P.; Mathe, C.; Cseke, K.; Szollosi, E.; M- Hamvas, M.; Jambrik, K.; Kiss, Z.; Meszaros, I. (2014). Osmotic stress responses of individual white oak (Quercus section, Quercus subgenus) genotypes cultured in vitro. Journal of Plant Physiology, 171(2): $16-24$.

Eroglu, H. (1988). LifLevhaEndüstriDersNotlari., Trabzon:K.T.Ü OrmanFakültesiYayin No:304.

Hafizoglu, H. and Reunanen, M.(1997). Composition of oleoresins from bark and cones of Abies nordmanniana and Picea orientalis. Holzforschung, 48:7-11.

Hafizoglu, H.; Usta, M. and Ozlem Bilgin (1997). Wood and bark composition of Picea orientalis L. Link. Holzforschung, 51:114-118.

Han, J.S. and Rowell, J.S. (1997). Chemical composition of agro-based fibers, Chapter 5. Paper and Composites from Agrobased Resources. CRC Press; pp:83-134.

Hedge, I.C. and Yaltirik, K. F. (1982). Quercus L. Flora of Turkey and East Aegean Islands, Vol. 7, Davisi, P. H. (Ed.).Edinburg: University Pres.

Keten, A.; Beskardes, V.;Kumbasli, M.;Makineci, E.; Zengin, H.;Özdemir, E.; Yilmaz, E.;Yilmaz, H.C.; Caliskan, S. andAnderson, J.T. (2015). Arthropod diversity in pure oak forests of coppice origin in northern Thrace (Turkey). iForest - Biogeosciences and Forestry, 8:615-623.

Kilic, A.; Hafizoglu, H.; Donmez, I.E.; Tumen, I.; Sivrikaya, H.; Reunanen, M. and Hemming, J. (2010). Extractives in the cones of Pinus species. Eur. J. Wood Prod., 69(1):37-40.

Lieutaghi, P. (1998). La plantecompagne 37. ActesSud.

Nahid Lorzadeh; Friba Sepavand, Maryam Soleimaninezhad and Nastaran Kazemirad, (2016). The effect of extract of Oak gall for vaginal tightening and rejuvenation in women with vaginal relaxation, Scientific Res., 6(13):1-7.

Sen, A.; Zhianski, M.; Glushkova, M.; Petkova, K.; Ferreira, J. and Pereira, H. (2016). Chemical composition and cellular structure of corks from Quercussuber trees planted in Bulgaria and Turkey. Wood Science and Technology, 50(6):1261-1276.

Shipra Shah; Jeet Ram; Nasir A. Pala; Priyanak Tripathi and Munesh Kumar (2014). Medicinal wealth of Oak dominated forests in Nainital catchment area of Uttarakhand, India. Academic Jounral of Medicinal Plants, 2(1):6-13.

Tappi, T. (1997). 204 om. Solvent extractives of wood and pulp. Atlanta Georgia: TAPPÝ Press, pp:1-4.

Tappi, T. (1999). 207 om. Water solubility of wood and pulp. Atlanta Georgia:TAPPÝ Press, pp:1-3.

Tappi, T. (2002). 211 om. Ash in wood, pulp, paper and paperboard, combustion at $525^{\circ} \mathrm{C}$. Atlanta Georgia: TAPPI Press, pp:1-5.

Tappi, T. (2002). 212 om. One percent sodium hydroxide solubility of wood and pulp. Atlanta Georgia: TAPPI Press, pp:1-4. 
Tappi, T. (2002). $257 \mathrm{~cm}$. Sampling and preparing wood for analysis. Atlanta Georgia: TAPPÝ Press; pp:1-3.

Todaro, L.; Dichicco, P.; Moretti, N. and D'Auria, M. (2013). Effect of combined steam and heat treatments on extractives and lignin in sapwood and heartwood of Turkey Oak (QuercuscerrisL.) Wood.Bioresources, 8(2): 1718-1730.

Wise, E.L. and Karl, H.L. (1962). Cellulose and hemicellulose in pulp and paper science and technolog. Newyork: Pulp, ed. C.E. Libby, Mc Grw Hill Book Co.
Yaltirik, K.F.(1984). Türkiye Meseleri Teshis Kilavuzu. Istanbul: Yenilik Basimevi, pp:66.

Yilmaz, A. (2017). Cytotaxonomic study of Quercus L. species from Section Quercus in Turkey.Caryologia: International Journal of Cytology, Cytosystematics and Cytogenetics, 70(2):141-146.

Zuzana Orszaghova; Iveta Waczulikova; Carolina Burki; Peter Rohde wald and Zdenka Durackva (2015). An effect of Oak wood extract on energy state of healthy adults; A. pilot study. Phytother. Res., 29(8):12191224. 